\title{
Dal rilievo all'analisi grafica della basilica di Santa Maria in Foro Claudio a Ventaroli
}

\author{
Piero Barlozzini \\ Laura Carnevali \\ Fabio Lanfranchi
}

Abstract

Nel Mezzogiorno d'Italia l'unico fatto rilevante occorso nell'XI secolo è l'avvicendamento tra il dominio normanno e longobardo. Tutti gli altri fatti non rappresentano che parti secondarie in questo 'dramma', a eccezione di Montecassino che esercita un'azione pastorale e culturale continua, talvolta discreta e talvolta palese, ma sempre importante, in Terra Sancti Benedicti come nei suoi dintorni.

Dopo la riforma dello spazio liturgico promossa dall'abate Desiderio -il religioso benedettino passato alla storia come papa Vittore III- adottata nell'abbazia benedettina di Montecassino, quella consacrata il $\mathrm{I}^{\circ}$ ottobre del $107 \mathrm{I}$, molte chiese furono costruite prendendo a modello quell'importante presidio religioso. Tra quelle sorte in prossimità del monastero cassinense troviamo a Ventaroli Santa Maria in Foro Claudio.

Questo studio rientra nell'ambito di un più ampio programma di lavoro che ci vede impegnati in questi anni a documentare il patrimonio architettonico nazionale poco noto al grande pubblico e in particolare è teso a individuare rapporti e proporzioni dell'impianto ecclesiastico considerati come parametri fondamentali per la conferma dell'epoca storica, l'analisi del linguaggio architettonico, il confronto con esempi analoghi e l'estrazione di regole che consentano di definire tipologie. L'indagine si avvale degli strumenti e delle metodologie proprie del disegno, del rilievo e dello studio dei documenti grafici e bibliografici conservati negli archivi storici.

Parole chiave

Santa Maria in Foro Claudio a Ventaroli, rilievo, analisi grafica, metrologia, architettura desideriana.

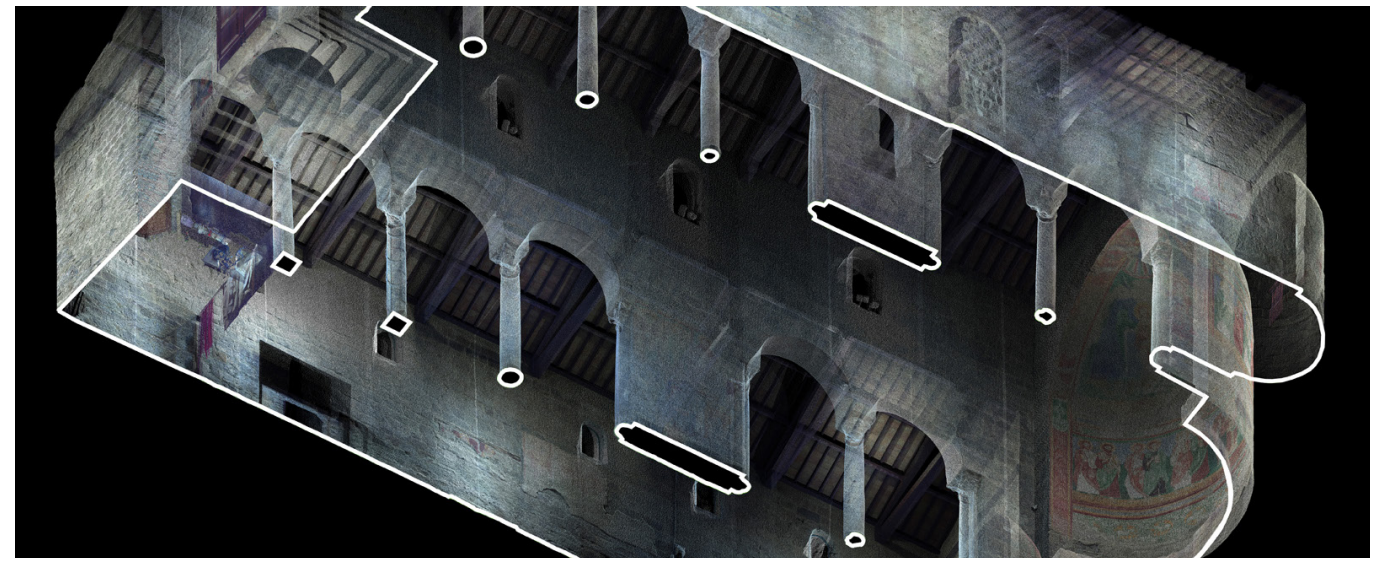




\section{Introduzione}

Ventaroli è un borgo immerso nel verde situato nel comune di Carinola, a circa 40 chilometri dalla città di Caserta (fig. I). Questo insediamento benché vanti antica fondazione è poco noto al grande pubblico per cui solo un ristretto numero di studiosi e appassionati di storia e architettura è al corrente che a poca distanza dall'abitato è ubicato uno dei capolavori artistici della Campania: la chiesa di Santa Maria in Foro Claudio; una struttura architettonica che gli studiosi fanno risalire all'XI secolo [Carbonara 20 I4, pp. 175, I76] ma con origini più antiche, probabilmente del $\vee$ secolo, secondo quanto testimoniano alcune porzioni dei paramenti murari perimetrali. Come si può intuire, questa chiesa è di estremo valore per la comunità locale poiché con la sua presenza discreta certifica il suo antico e fervido spirito cristiano, ma è un manufatto architettonico prezioso anche per il patrimonio artistico italiano dato che al suo interno contiene alcuni affreschi di straordinaria bellezza artistica di varia datazione.

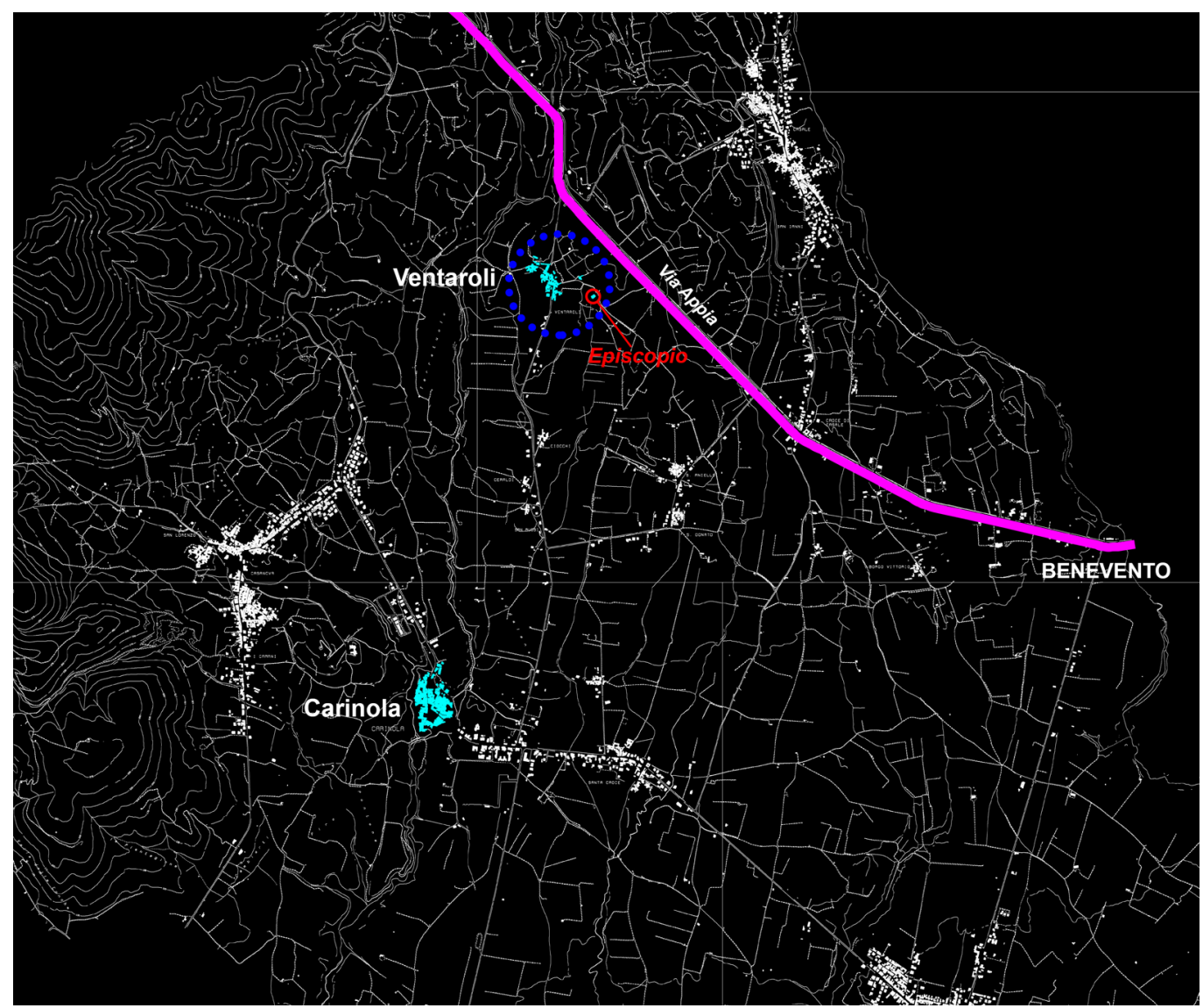

\section{Spazio liturgico della chiesa}

La chiesa di Ventaroli consacrata a Maria (fig. 2) ha rivestito un ruolo importante come presidio religioso anche per la Chiesa di Roma dato che fu sede vescovile probabilmente dalla seconda metà del V secolo [Miraglia, Valente 20 I3, p. 7] sino alla fine del XI secolo, quando il centro diocesano fu spostato nella vicina Carinola [Marini Ceraldi 1990, p. 40].

Nello specifico, l'architettura del sacro foroclaudiense è una struttura basilicale realizzata in stile romanico che rispecchia il clima culturale desideriano di Montecassino. L'edifico è orientato secondo la direzione nord-est/sud-ovest e misura 20,66 m in lunghezza e I3,98 $\mathrm{m}$ in larghezza, compresi gli spessori dei muri con esclusione dei volumi absidali. 
Fig. 2. Fronte principale della basilica di Santa Maria in Foro Claudio.

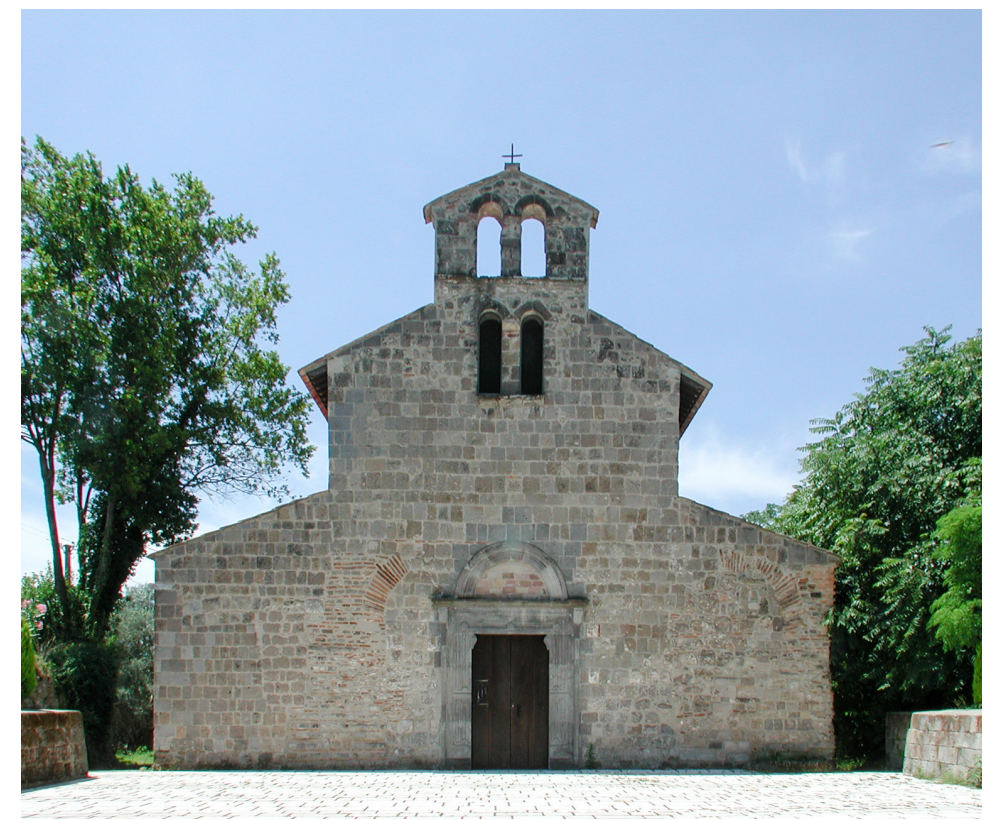

L'accesso alla basilica è assicurato da un portale architravato posto a levante realizzato in stile catalano [I].Tra il piano di calpestio del sagrato e quello dell'aula assembleare esiste un dislivello di circa I,50 m (fig. 3) per cui oltrepassata la soglia d'ingresso si scendono alcuni gradini per arrivare al pavimento della chiesa (fig. 4). Una volta entrati nell'edifico ci si ritrova in uno spazio architettonico tripartito, illuminato dal cleristorio e da una serie di fessure poste sul paramento murario sinistro. I diaframmi longitudinali sono composti da strutture architettoniche puntiformi e setti murari tutti costituiti da elementi di spoglio assemblati con

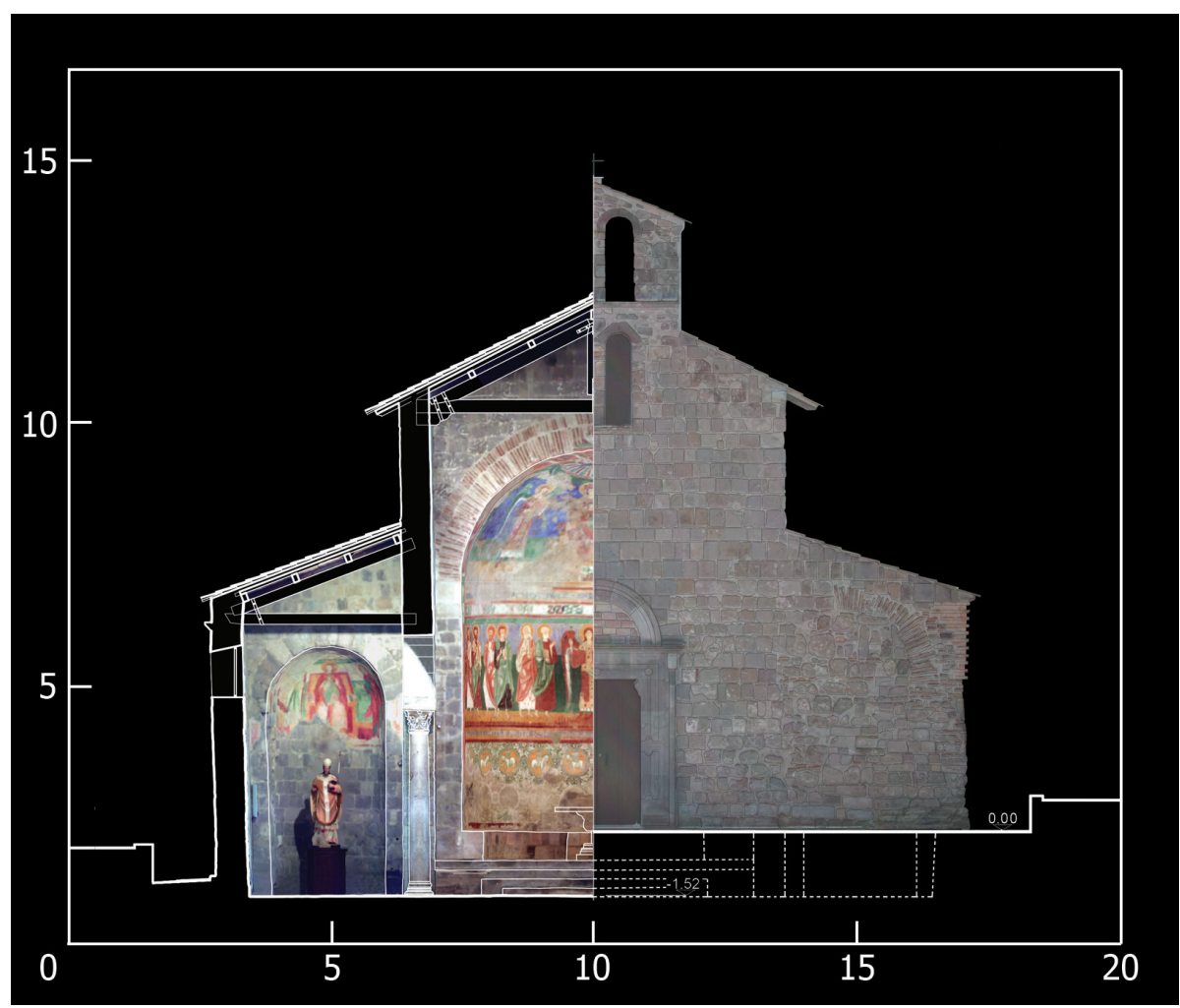

Fig. 3. Disegno composto a destra dal semi-

prospetto principale e

a sinistra dal semi-

prospetto del fronte

absidale interno elaborati da modelli mesh. 
cura, in modo attivo come scrive Carlo Tosco [Tosco 20 I3, p. I 3], al di sopra sono impostati archi a tutto sesto; la copertura della navata centrale, caratterizzata da orditura alla lombarda, è sorretta da capriate lignee, le falde di quelle laterali si appoggiano su pseudo capriate asimmetriche (fig. 5). Le tre navate sulla parete ovest sono caratterizzate da absidi semicircolari (fig. 6). L'altare delle celebrazioni liturgiche è unico ed è posto sull'asse longitudinale della chiesa sopra il calpestio del presbiterio rialzato su gradini (fig. 7). La chiesa è priva di transetto e cripta e oggi anche di pulpito e di sedia vescovile, una circostanza che non ci sorprende più di tanto poiché entrambi questi fuochi della liturgia cattolica probabilmente erano costruiti in legno che il tempo inesorabilmente ha distrutto durante gli anni di incuria. La sezione muraria, completamente visibile all'esterno e quasi completamente all'interno, è caratterizzata dalla tecnica costruttiva a opus quadratum. "L'uso dell'opera quadrata si è esteso, in parte, anche all'architettura religiosa, in modo specifico nel territorio alto-campano, dove si registrano interventi che prevedono il reimpiego di materiale di spoglio" [Crova 2005, p. II0].
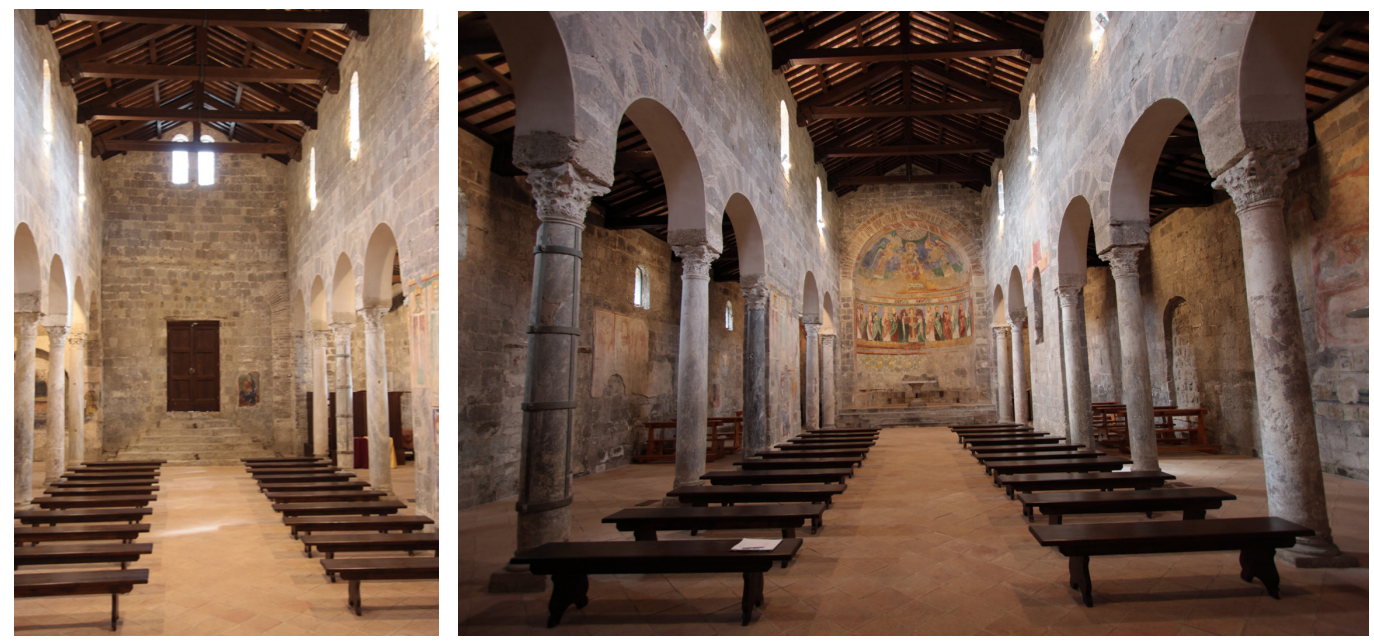

\section{Rilevamento e restituzione}

Nel caso specifico il rilievo metrico e fotografico è seguito alla fase di ricerca documentale effettuata presso gli archivi della Soprintendenza archeologica, belle Arti e Paesaggio delle province di Caserta-Benevento e Napoli, nell'Archivio Storico del Comune di Carinola e in quello della diocesi di Sessa Aurunca, dove sono confluiti i documenti della cattedra diVentaroli e di Carinola a seguito della soppressione di questa sede vescovile dopo il concordato tra Santa Sede e il Regno borbonico.

Per il raggiungimento degli obiettivi prefissati, è stato elaborato un progetto di rilievo finalizzato a conoscere e rappresentare il manufatto nel suo insieme come nella specificità degli elementi architettonici, materici, strutturali, e decorativi. In conseguenza di ciò è stata programmata l'organizzazione dell'attività secondo differenti fasi e livelli di approfondimento. Il progetto di rilievo ha previsto l'integrazione di metodologie e tecniche differenti, sia nella fase di acquisizione dei dati che in quella di post-processing e di restituzione, al fine di ampliare le possibilità operative e l'efficacia dei risultati. Contemporaneamente alla prima fase di effettivo 'contatto' con il manufatto, esperita mediante il rilevamento diretto finalizzato all'acquisizione delle informazioni metrico-dimensionali soprattutto di dettaglio, si è proceduto con una campagna di acquisizione fotografica 'tradizionale', effettuata con una macchina digitale Canon EOS 40D. Concluso il primo approccio conoscitivo si è passati all'attività di rilevamento strumentale massiva attuata con il laser scanner FARO Focus 3D SI20, con il quale sono state acquisite 19 scansioni a media risoluzione sia esterne che interne al manufatto. 
Nella successiva fase di elaborazione dei dati sono state effettuate le rimozioni degli elementi di disturbo: elementi fisici estranei al manufatto, outliers derivanti da errori di scansione dovuti a superfici molto riflettenti, o umidità e/o polvere, ma anche 'rumore' rappresentato ad esempio dai mixed pixel.

In fase di acquisizione dati sono stati individuati e annotati su opportuni eidotipi, una serie di punti ben visibili e riconoscibili, sia all'interno che all'esterno del manufatto. Questi target, una volta collimati da diverse stazioni con la total station Leica TCR 703, sono stati utilizzati nel processo di unione tra le diverse nuvole permettendo quindi la strutturazione di un comune sistema di riferimento. Per quanto attiene il processamento dei dati (unioni nuvole, elaborazione piante, profili e orto-immagini) si è utilizzato il software JRC Reconstructor, della software house Gexcel. I dati elaborati sono quindi stati esportati e trattati mediante software CAD per quanto attiene la definizione architettonica più tradizionale, mentre per le operazioni inerenti al post-processing (editing, texturing e meshing), sono stati utilizzati due free-software CloudCompare e MeshLab, impiegati in accordo con le finalità della rappresentazione (fig. 8).

Fig. 6. Zona absidale esterna della basilica Claudio.

Fig. 7. Scorcio di dettaglio del presbiterio, sullo sfondo il ciclo pittorico dell'abside maggiore.
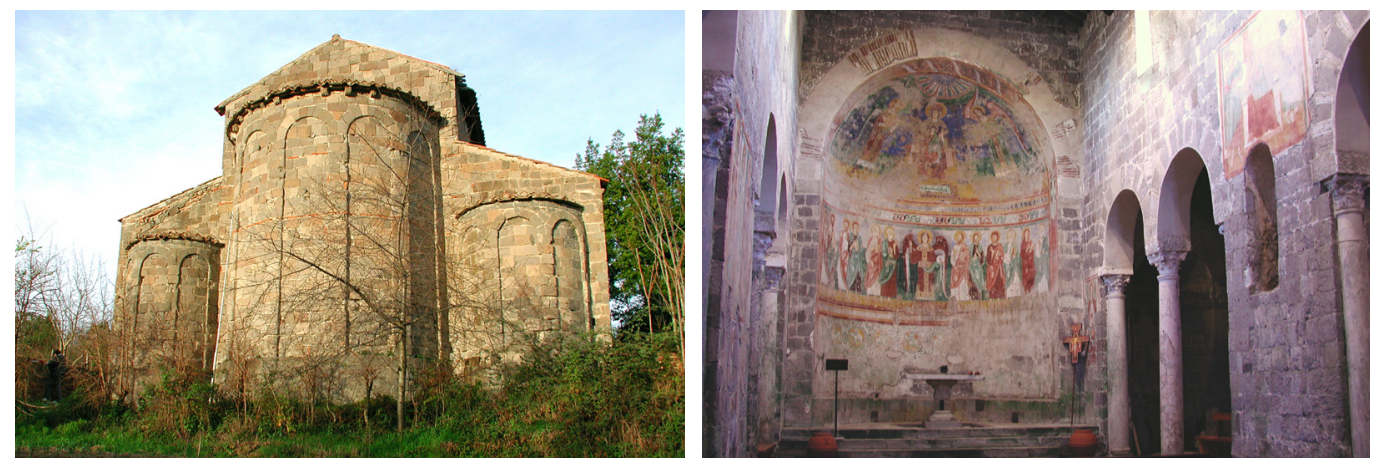

\section{Analisi grafico-metrologica}

Sulla scorta delle ricostruzioni in scala metrica, effettuate in ambiente CAD mediante l'elaborazione dei dati derivanti dalle acquisizioni, lo studio è stato orientato verso l'individuazione di un plausibile sistema di misura adottato per l'edificazione della struttura, anche in considerazione dell'assenza di studi metrologici dedicati a questo manufatto. In relazione alle peculiarità dell'ambito geografico e del periodo di costruzione del manufatto occorre premettere che i canoni di misura utilizzati nelle diverse fabbriche destinate al culto, si caratterizzano per una sostanziale apertura e variabilità in dipendenza di fattori più disparati, tra $\mathrm{i}$ molti possiamo enunciare a titolo semplificativo ma non esaustivo, quelli teorico-mistagogici. In ogni caso la basilica di Santa Maria in Foro Claudio è annoverabile nell'insieme degli edifici ideati secondo lo schema compositivo della "rinascenza desideriana", il filone culturale dell'XI secolo il cui primo e più illustre fautore fu l'abate Desiderio di Montecassino; come suggerisce Giovanni Carbonara il modello di chiesa auspicato da Desiderio era "antico e moderno al tempo stesso" [Carbonara 2014, p. 27]. A ogni buon conto, prescindendo al momento da possibili considerazioni sui caratteri di ordine geometrico-proporzionale, in termini metrologici emerge che il cubito è l'unità di misura utilizzata da Leone Marsicano nel I I59 per la descrizione dimensionale degli ambienti dell'abbazia di Montecassino, consacrata nel I07I [Aceto, Lucherini 200I, pp. 47-49]. Ma contemporaneamente, per la chiesa benedettina di Sant'Angelo in Formis, viene osservato l'impiego del piede romano e del cubito italico, con prevalenza del primo [Carbonara 20 I4, p. 174]. Ai fini del prosieguo del nostro discorso, riteniamo quindi lecito effettuare qualche considerazione che possa rivelarsi utile al fine di stabilire, con un ragionevole livello di determinazione, quale possa essere effettivamente stato il canone mensorio adottato per la realizzazione della fabbrica. 


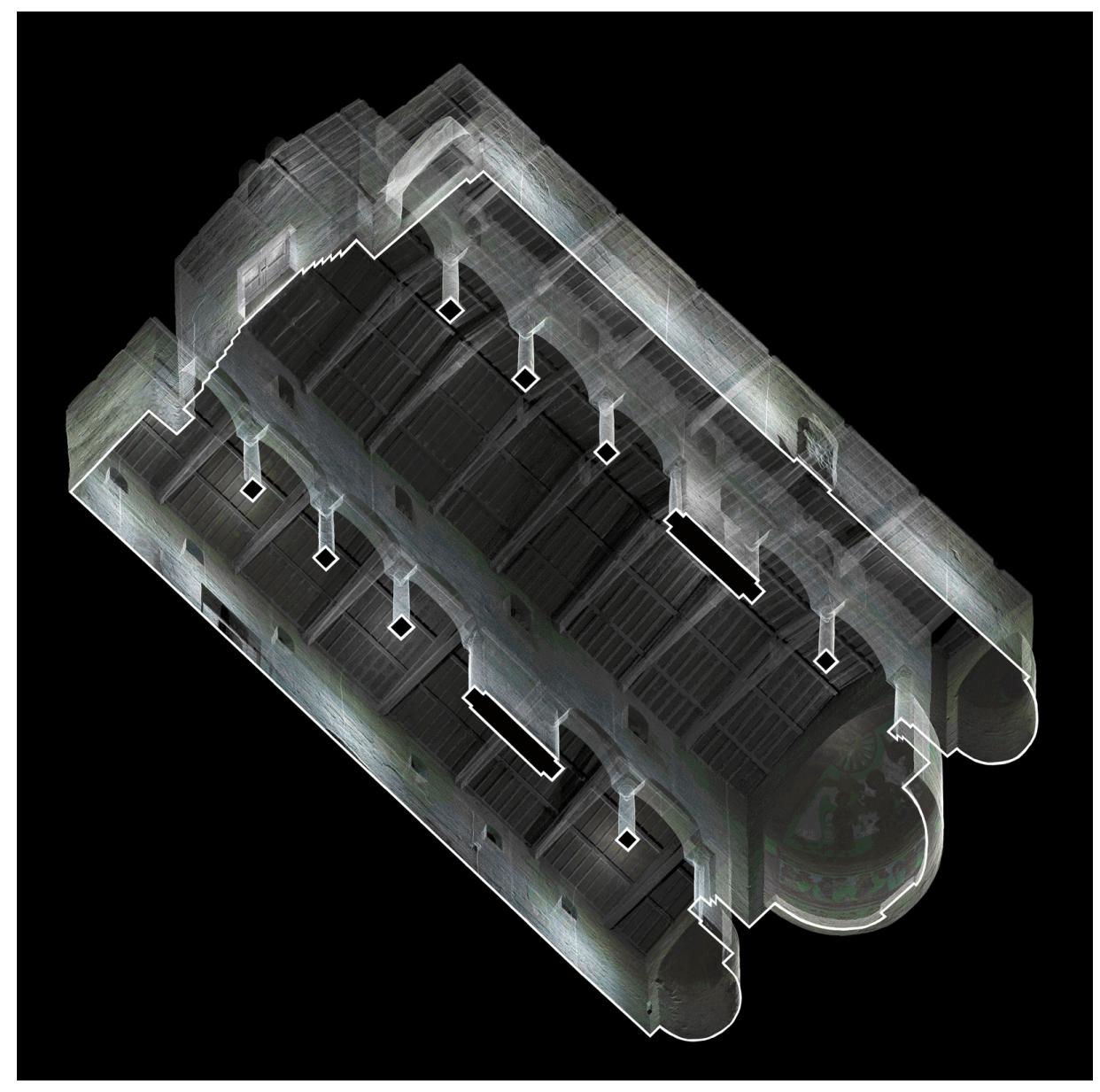

\section{II cubito}

In ambito metrologico, oltre al cubito reale e al cubito corto suo sottomultiplo, ricorre il cubito italico e del piede romano che, sia pure con limitate variazioni di lunghezza in termini di $\mathrm{mm}$, rappresenta il riferimento o in altre parole il modulo originario per tutte le 'declinazioni' del cubito.

Ed in effetti 7 piedi romani corrispondono a 4 cubiti reali di lunghezza unitaria pari a 525 $\mathrm{mm}$, mentre 3 piedi romani corrispondono al doppio del sottomultiplo del cubito reale, ossia al cubito naturale. In definitiva "Si distinguono un cubito naturale e un cubito reale, modulare al primo in ragione del palmo 7:6, un palmo in più ma più utile nelle misurazioni dell'impianto di cantiere in contrapposizione al primo, il cubito naturale, più pratico per le misurazioni locali dei dettagli architettonici"' [Aiello 20 I8, p. 5I].

Formato da 6 palmi è inoltre il cubito italico, che si attesta invece su una lunghezza unitaria di 444 mm [Segrè 1927, pp. I40, I I ] , corrispondenti a 74 mm per palmo, un modulo che trova la corrispondenza con il piede romano -in questo caso da $296 \mathrm{~mm}$ - ogni 9 cubiti (fig. 9). Ciò premesso in ambiente CAD si è messa a confronto la planimetria della basilica sezionata a $20 \mathrm{~cm}$ di altezza rispetto al piano di calpestio interno [2], con i due distinti dispositivi metrologici, uno conformato da moduli corrispondenti a cubiti reali e ai relativi sotto cubiti corti, l'altro da cubiti italici; in tutti e due i casi sono stati riportati i corrispondenti piedi romani.

Il confronto tra la pianta dell'edificio escluse le sagome delle absidi, rappresentata mediante un rettangolo il più possibile coerente con la sagoma non regolare dell'impianto [3], e i dispositivi di misura predisposti, ha evidenziato [4] la piena corrispondenza dimensionale con il cubito reale. 
Di non secondario interesse, inoltre, l'esito derivante dalla corrispondenza tra il valore dimensionale espresso in cubiti e relativi sottomultipli rispetto ai piedi romani; a fronte dei valori dimensionali di larghezza e lunghezza della fabbrica rispettivamente pari a 26 cubiti reali e 2 palmi per 39 cubiti reali e 3 palmi, è corrisposta una coppia di valori interi, ossia 46 per 69 piedi romani (fig. 10). Alla luce di quanto emerso riteniamo probabile che l'edificio sia stato ideato e costruito mediante l'impiego combinato tra il piede romano e il cubito con possibile prevalenza del primo, così come osservato per la chiesa benedettina di Sant'Angelo in Formis.

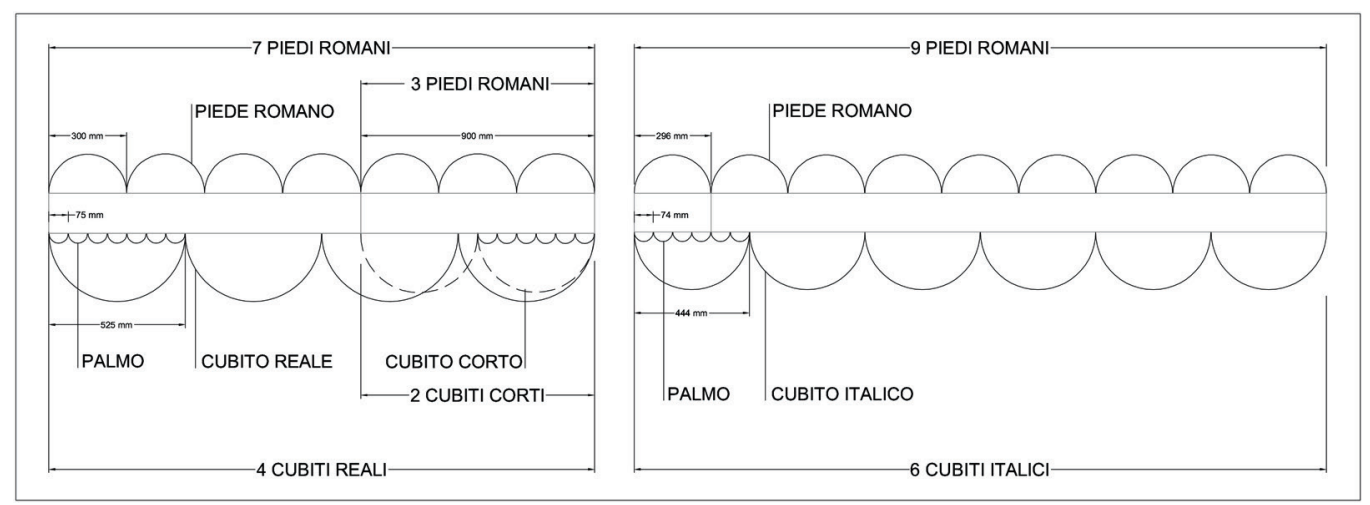

\section{Le proporzioni}

Individuata la relazione tra larghezza e lunghezza del manufatto, si è ritenuto opportuno effettuare alcune considerazioni sui dati di proporzione derivanti; in particolare il rapporto dimensionale tra i due lati [a] per la larghezza e [b] per la lunghezza, definisce uno dei rettangoli armonici, e in particolare quello corrispondente al diapente, caratterizzato dai rapporti $[\mathrm{a} / \mathrm{b}]=0,6666 \ldots[\mathrm{b} / \mathrm{a}]=1,5$ e quindi con rapporto tra i lati di 2:3 [5] (fig. I I). Relativamente allo studio delle proporzioni interne si è individuato il rapporto tra diametro interno dell'abside maggiore e la lunghezza della chiesa; in particolare la dimensione del diametro ripetuta quattro volte, determina la lunghezza interna dell'edificio misurata in corrispondenza del filo esterno della soglia. Come noto nel medioevo, l'uso di un modulo pari al diametro absidale era un sistema ricorrente di proporzionamento planimetrico delle aule di culto, utile a regolarne la lunghezza che, in alcuni casi, la larghezza [6]. Per quanto attiene il dato metrologico, si osservi come il diametro, definito da undici cubiti naturali, si conformi all'unità di misura prevalentemente utilizzata per misurazioni locali e di dettaglio. Considerazione che risulta confermata anche osservando i dati dimensionali esplicitati nella sezione trasversale visibile nella (fig. 12). L'altezza interna della chiesa riferita alla quota altimetrica intermedia del piano di calpestio attuale molto probabilmente non corrispondente a quello originale [7], corrisponde a 25 cubiti naturali, a | 3,5 cubiti naturali corrisponde la quota d'imposta della calotta absidale, mentre la quota d'imposta degli archi sovrastanti i diaframmi longitudinali risulta pari a 8,5 cubiti naturali.

\section{Conclusioni}

Gli studi esemplificati sulla presente trattazione rientrano, come precedentemente accennato, nell'ambito di un più ampio programma di lavoro finalizzato alla conoscenza e alla documentazione dell'intero manufatto. II contributo, che non può certamente essere considerato esaustivo, riteniamo possa aprire comunque verso una possibile chiave interpretativa del manufatto che, partendo dalla misura e passando per la geometria riteniamo conduca 
verso l'orizzonte della mistagogia, a sua volta strumento di indagine ma al contempo di riscontro alle teorie più propriamente fisiche precedentemente formulate. In definitiva una sorta di innesco di un processo di continui rimandi sospesi tra il tangibile e l'intangibile, tra l'evidenza e la latenza.

Fig. 10. Analisi graficometrologica planimetrica delle murature e rapporti proporzionali della

basilica di Santa Maria in Foro Claudio.

Fig. II.Analisi grafica della planimetria delle murature e rapporto proporzionale della

basilica di Santa Maria in Foro Claudio.
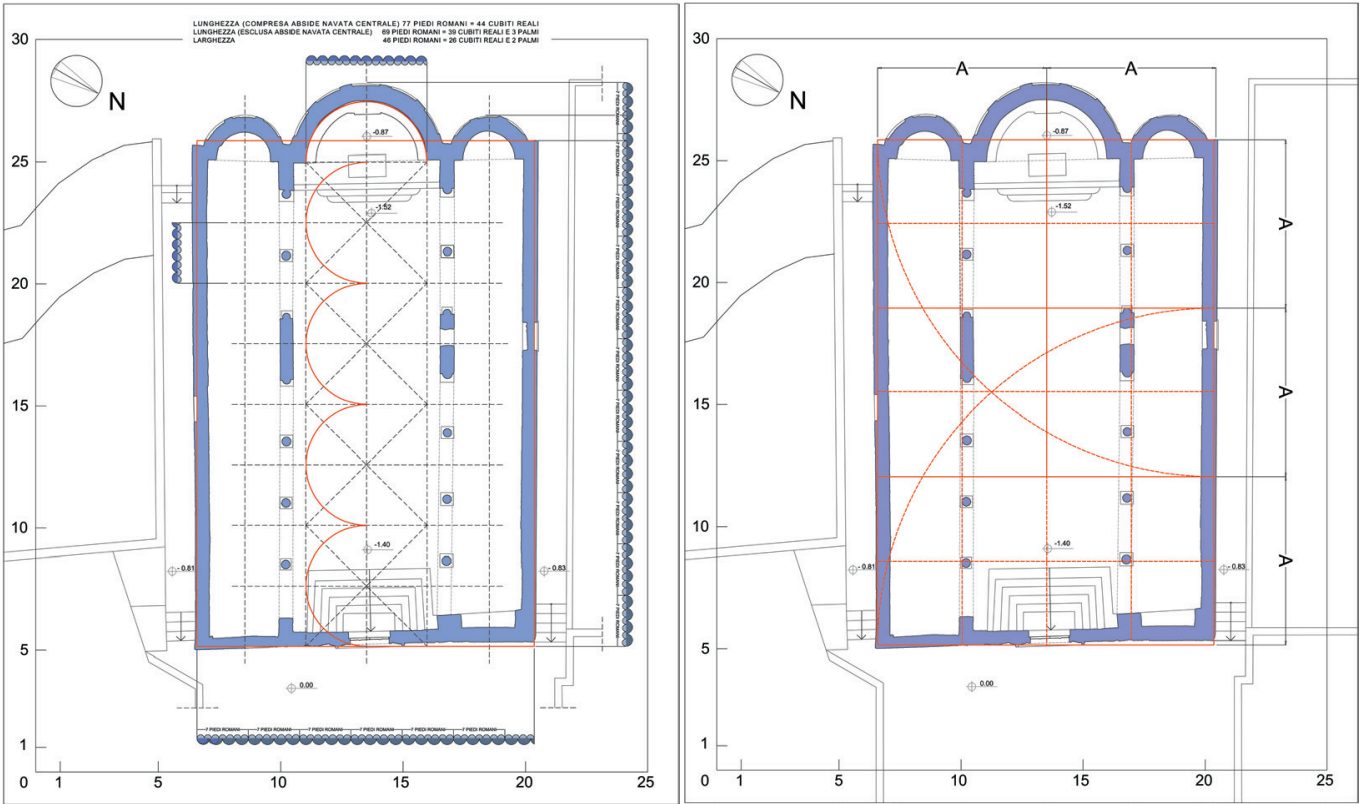

Fig. 12. Analisi graficometrologica della sezione trasversale della basilica di Santa Maria in Foro Claudio. Con il tratteggio è rappresentata la proiezione del saliente provrastante la navata centrale. Si noti come in centra Si noti come in misura risulti configurato misura risulti configurato sui cubiti naturali.

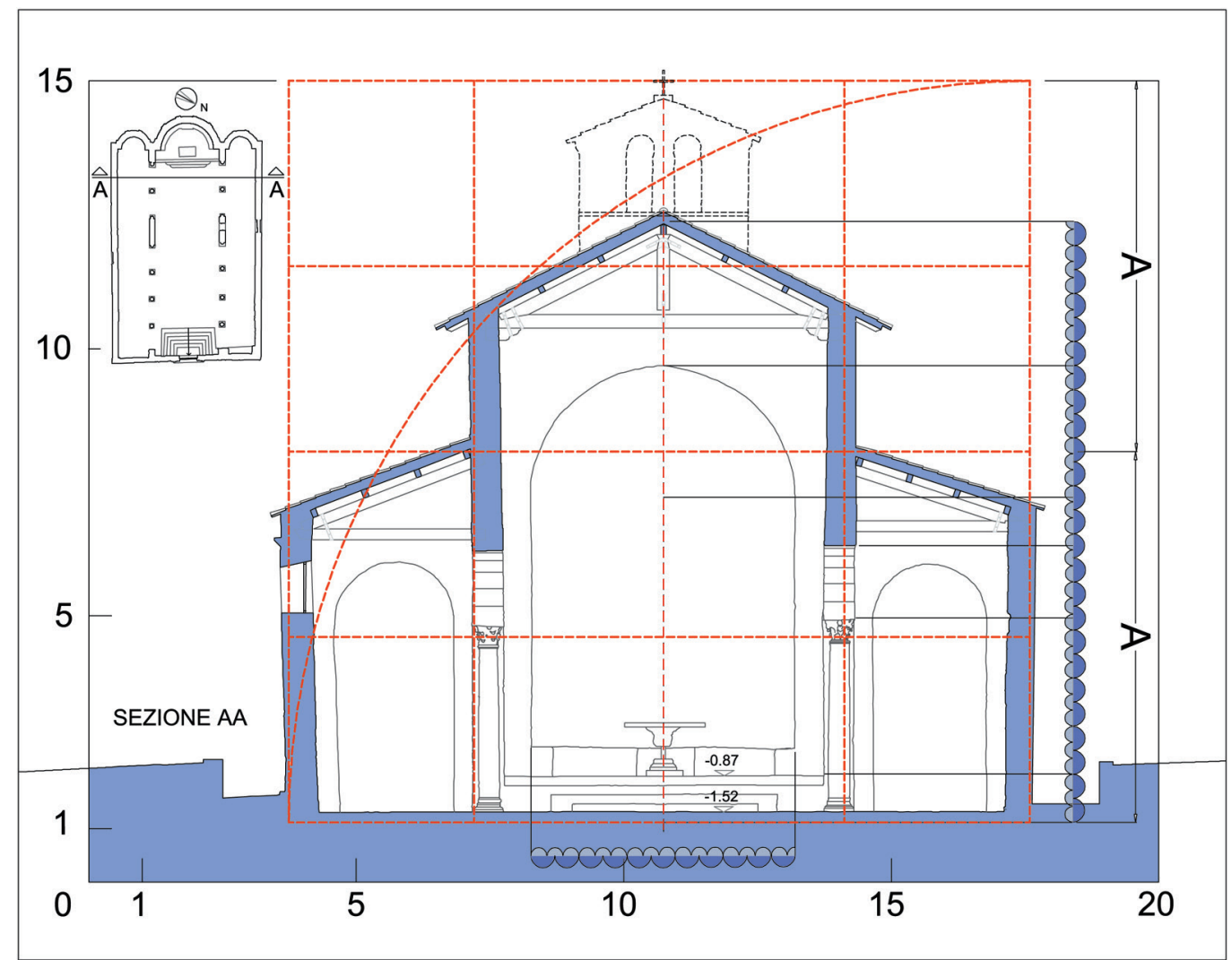




\section{Note}

[I] Per approfondimenti cfr. ad esempio Barlozzini, Carnevali, Lanfranchi 2020.

[2] Una scelta obbligata al fine di limitare le deformazioni dovute alla progressiva deformazione delle murature in alzato causata da antichi cedimenti in seguito ridotti da operazioni di consolidamento.

[3] La pianta di rilievo evidenzia la convergenza delle 2 sezioni murarie laterali di $10 / 12 \mathrm{~cm}$ verso il fronte di accesso, oltre alla rotazione dei 2 fronti corti rispetto all'asse di $20 \mathrm{~cm}$, una probabile evidenza di come l'impianto sia stato preceduto da altre strutture che potrebbero averne influenzato l'andamento delle pareti e l'orientamento.

[4] Nei limiti oggettivi del grado di approssimazione legato all'incertezza dei procedimenti e degli strumenti di misura utilizzati e dei possibili errori dell'operatore [Docci, Maestri 2009].

[5] Per più opportuni approfondimenti si veda: Dotto 2002, pp. 75-80.

[6] Per quanto concerne questo tipo di proporzionamento si veda: ad esempio Acierno 20 I3, p. I88.

[7] Dai grafici di rilievo si evince che il piano del calpestio, posato in opera nel corso dell'ultimo restauro, ha una pendenza verso il presbiterio di circa 15 cm [Barlozzini, Carnevali, Lanfranchi 2020, pp. 9, I0].

\section{Riferimenti bibliografici}

Aceto F., Lucherini V. (a cura di). (200 I). Leone Marsicano Cronaca di Montecassino (III 26-33). Milano: Jaca Book, pp. 47-49.

Acierno M. (20 I3). Magistra Latinitas. L'architettura dell'XI secolo in Terra di Lavoro tra permanenza e innovazione. Roma: Ginevra Bentivoglio EditoriA.

Aiello L. (2018). Il cubito biblico. Misura di tutte le cose. Firenze: Didapress.

Barlozzini P., Carnevali L., Lanfranchi F. (2020). La basilica di Santa Maria in Foro Claudio a Ventaroli: analisi e rilievo di un periferico monumento medievale. In Quaderni dell'Istituto di Storia dell'Architettura, n.s. 72. Roma: L'Erma Di Bretschneider, pp. 5-18.

Carbonara G. (20I4). Iussu Desiderii, Montecassino e l'architettura campano-abruzzese nell'XI secolo. Roma: Ginevra Bentivoglio EditoriA.

Crova C. (2005). Murature medievali in opus quadratum: il Lazio meridionale e la Terra di Lavoro. Raffronti e specificità costruttive. In: D. Fiorani, D. Esposito (a cura di). Tecniche costruttive nell'edilizia storica, pp. I05-I I 8. Roma: Viella.

Docci M., Maestri D. (2009). Manuale di rilevamento architettonico e urbano. Bari: Laterza.

Dotto E. (2002). Il disegno degli ovali armonici. Catania: le Nove Muse Editrice.

Marini Ceraldi A. (1990). La basilica di S. Maria in Foro Claudio. Marina di Minturno: Armando Caramanica Editore.

Miraglia F., Valente C. (20I3). Note sulla continuità del mondo antico nell'architettura sacra e nella scultura del medioevo tra la Campania Felix ed il Latium adiectum. I casi di Carinola, Sessa Aurunca e Minturno. Marina di Minturno: Armando Caramanica Editore.

Segrè A. (1927). Metrologia e circolazione monetaria degli antichi. Bologna: Zanichelli.

Tosco C. (2016). L'architettura Medievale in Italia 600-1200. Bologna: il Mulino.

\section{Autori}

Piero Barlozzini, Università degli Studi del Molise, piero.barlozzini@unimol.it

Laura Carnevali, Sapienza Università di Roma, laura.carnevali@uniromal.it

Fabio Lanfranchi, Sapienza Università di Roma, fabio.lanfranchi@uniromal.it

Per citare questo capitolo: Barlozzini Piero, Carnevali Laura, Lanfranchi Fabio (2021). Dal rilievo all'analisi grafica della basilica di Santa Maria in Foro Claudio a Ventaroli/From surveying to graphical analysis of the Basilica of Santa Maria in Foro Claudio in Ventaroli. In Arena A., Arena M. Mediati D., Raffa P. (a cura di). Connettere. Un disegno per annodare e tessere. Linguaggi Distanze Tecnologie. Atti del $42^{\circ}$ Convegno Internazionale dei Docenti delle Discipline della Rappresentazione/Connecting. Drawing for weaving relationship. Languages Distances Technologies. Proceedings of the $42^{\text {th }}$ International Conference of Representation Disciplines Teachers. Milano: FrancoAngeli, pp. 197-2 |4. 


\title{
From Surveying to Graphical Analysis of the Basilica of Santa Maria in Foro Claudio in Ventaroli
}

\author{
Piero Barlozzini \\ Laura Carnevali \\ Fabio Lanfranchi
}

\section{Abstract}

In southern Italy, the only relevant event in the eleventh century was the alternation between the dominions of the Normans and Lombards. All other facts are only secondary aspects in this 'drama'. The only exception is Montecassino, which exerted continuous pastoral and cultural influence -sometimes moderate, sometimes clear, but always important- in Terra Sancti Benedicti and its surroundings. After the reorganization of the liturgical space for the Benedictine Abbey of Montecassino (consecrated on I October 107I) promoted by the abbot Desiderius -better known to history as Pope Victor III- many churches were built on the model of that important religious site. Those located near the monastery include Santa Maria in Foro Claudio in Ventaroli.

This study falls within a broader programme whose scope is to document parts of the national architectural heritage that are little known to the general public. In particular, it extends to identifying relationships and proportions of the ecclesiastical layout considered as fundamental parameters in confirming the historical era, the analysis of architectural language, comparison with analogous examples, and extraction of the rules that enable definition of the typology. This investigation relies on the tools and methods of drawing, surveying, and the study of graphical and bibliographic documents stored in historical archives.

\section{Keywords}

Santa Maria in Foro Claudio in Ventaroli, surveying, graphical analysis, metrology, architecture under Desiderius.

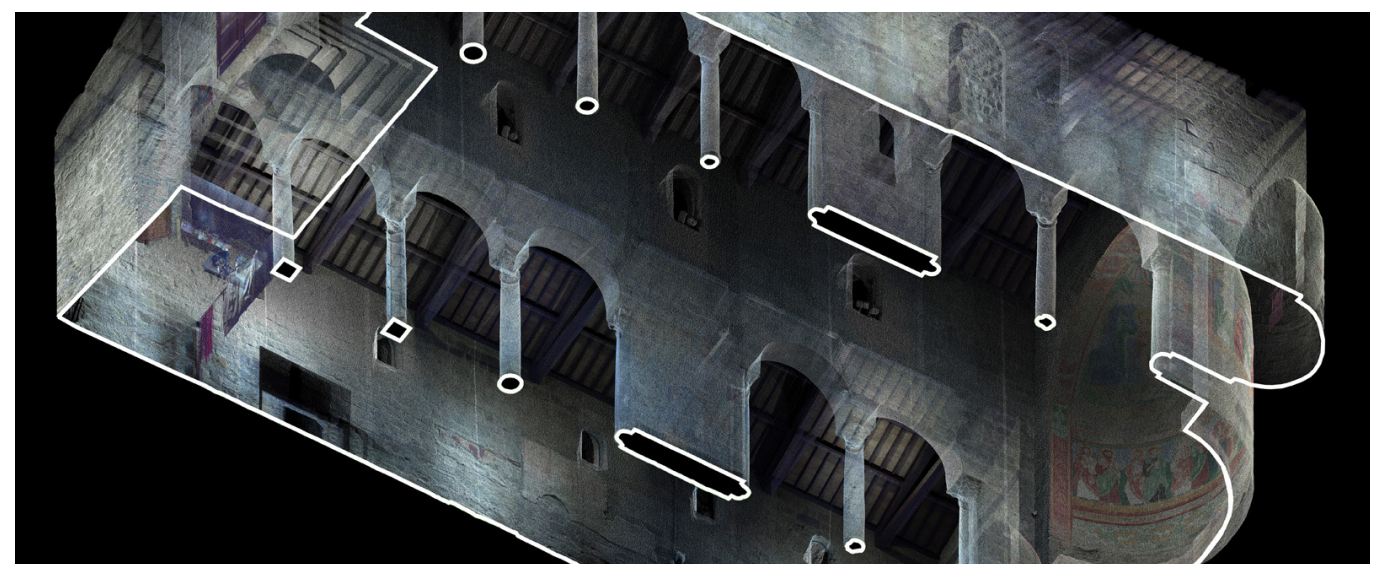




\section{Introduction}

Ventaroli is a village surrounded by nature in the municipality of Carinola, about 40 kilometres from the city of Caserta in the Campania Region (fig. I). Although the settlement rests on ancient foundations, it is little known by the larger public, due to which only a small number of scholars and history/architecture enthusiasts are aware that just a short distance from the residential area lies a work of art: the Church of Santa Maria in Foro Claudio. Scholars have dated this architectural structure to the eleventh century [Carbonara 2014, pp. 175, 176], but it is probably much older - from the fifth century as evidenced by portions of the perimeter wall facing. As can be inferred, this church holds great value for the local community because its discrete presence testifies to the ancient and fervid Christian spirit, but it is also a valuable architectural building for the Italian cultural heritage since it contains extraordinary and artistically beautiful frescoes of various ages.

Fig. I. Partial plan of the area of Carinola. The residential area of Ventaroli and the Church of Santa Maria in Foro Claudio are highlighted.

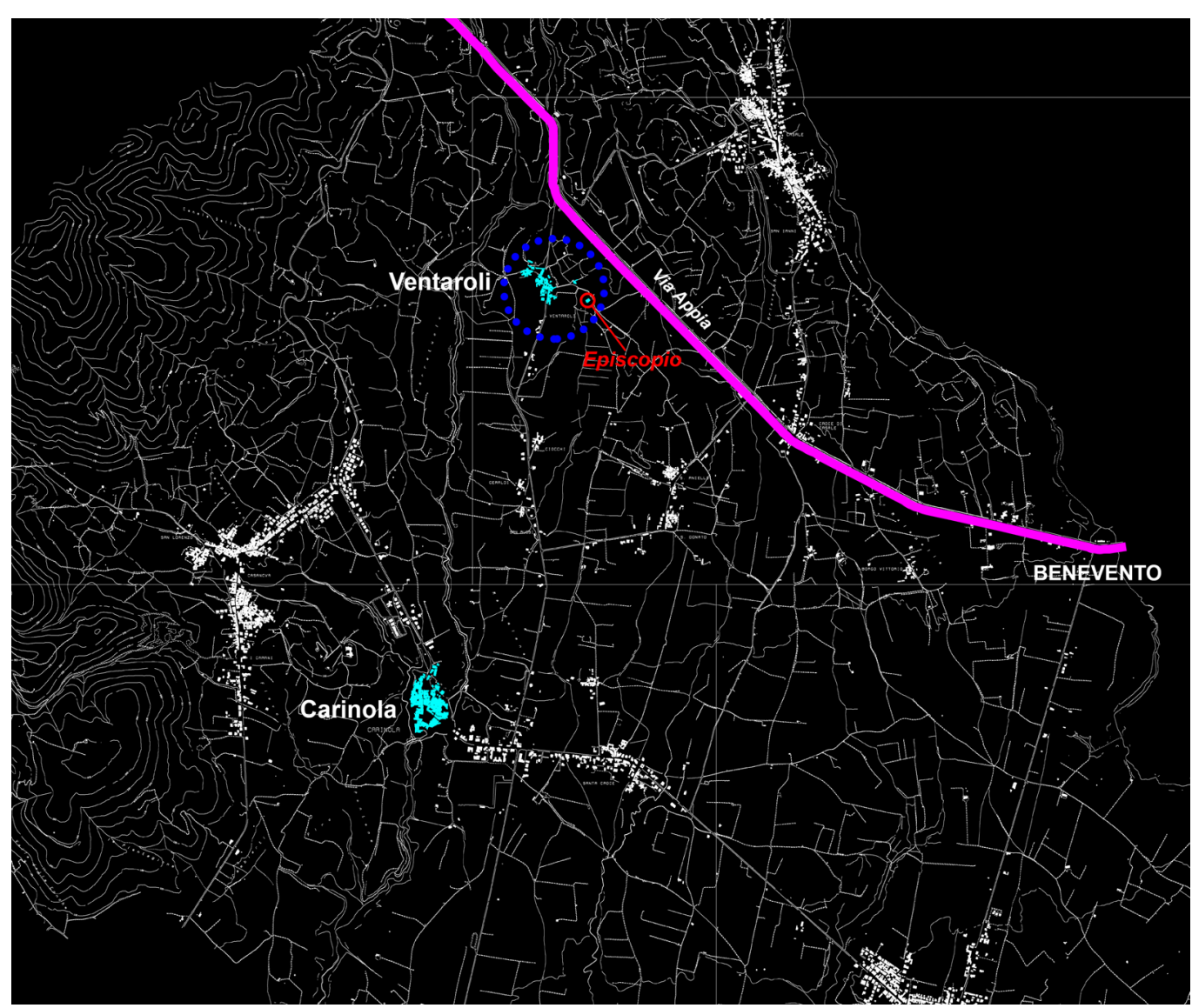

\section{Liturgical space of the church}

This church in Ventaroli, dedicated to Mary (fig. 2) also played an important role as a religious stronghold for the Church of Rome given that it served as the bishopric, probably from the latter half of the fifth century [Miraglia,Valente 2013, p. 7] to the end of the eleventh century when the diocesan centre was moved to nearby Carinola [Marini Ceraldi 1990, p. 40]. Specifically, the architecture of the church presents a basilica structure built in the Romanesque style, reflecting the cultural climate under Desiderio of Montecassino. The building is oriented along the north-east/south-west direction and measures $20.66 \mathrm{~m}$ long by $13.98 \mathrm{~m}$ wide, including the thickness of the walls but excluding the apses. 
Fig. 2. Main façade of the Basilica of Santa Maria in Foro Claudio.

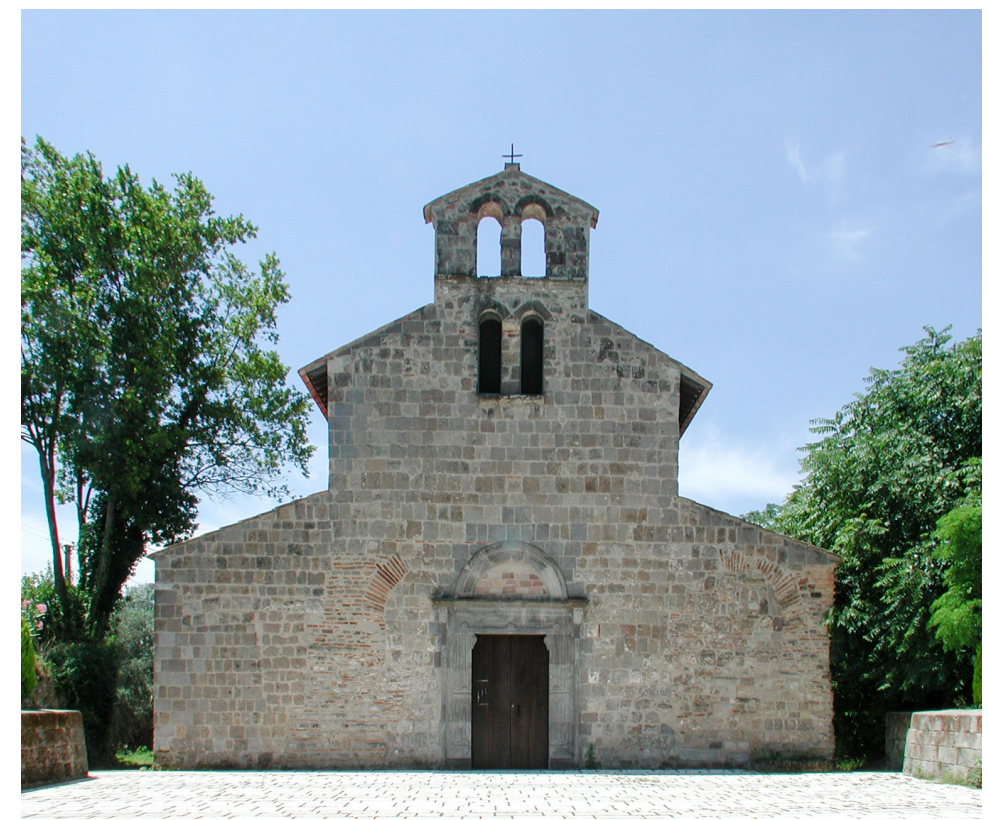

The entrance to the basilica is situated in the east; it consists of door with architrave realized in a Catalan style [I]. Between the floor of the porch and the assembly hall there is a height difference of about $1.50 \mathrm{~m}$ (fig. 3), so upon passing through the doors, one descends a few steps to reach the floor of the church (fig. 4). Once in the building, we find a trisected architectural space lit by the clerestory and a series of slats in the left wall. The longitudinal separations are composed of point-like architectural structures and walls, all consisting of spolia carefully and actively assembled, as Carlo Tosco writes [Tosco 2013, p. I3], and on which

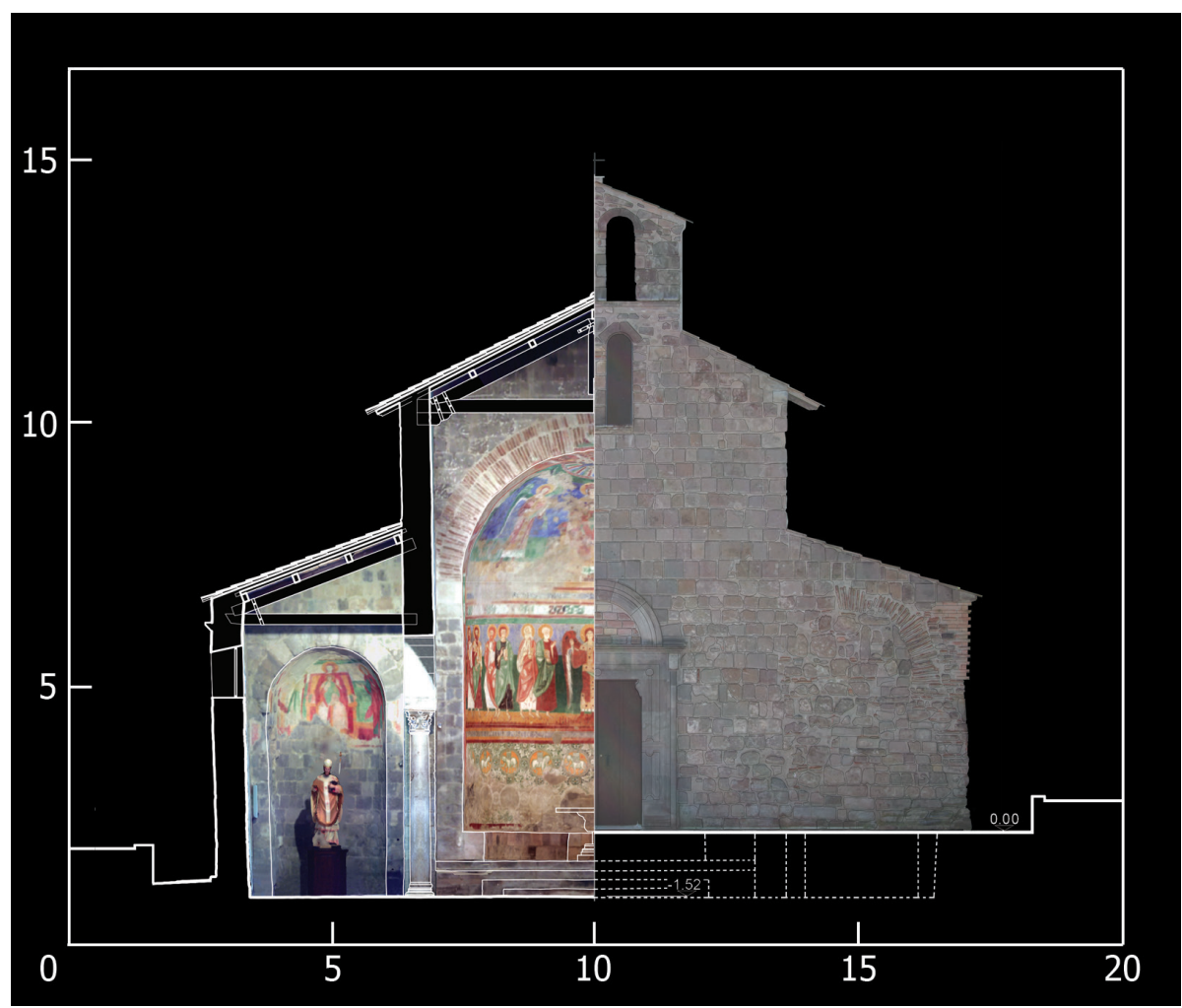


rounded arches rest. The ceiling of the central nave, characterized by Lombard scaffolding, is supported by wooden trusses; the ceilings of the side aisles rest on asymmetric pseudo trusses (fig. 5). The three aisles end at the western wall in semicircular apses (fig. 6). There is one altar for liturgical celebrations situated along the longitudinal axis of the church on the presbytery, which is raised by a few steps (fig. 7). The structure has no transept or crypt, nor today does it have a pulpit or cathedra, circumstances that are not surprising because these foci of the Catholic liturgy were probably made of wood, which time inexorably destroyed over years of neglect. The wall section, fully visible on the exterior and almost completely inside, is characterized by the opus quadratum construction technique. "The use of opus quadratum also partly extends to religious architecture, specifically in the upper Campania area, where there are interventions that involve the use of spolia" [Crova 2005, p. II0].

Fig. 4. Main façade with entrance stairs seen from within.

Fig. 5. Interior view of the church seen from the entrance.
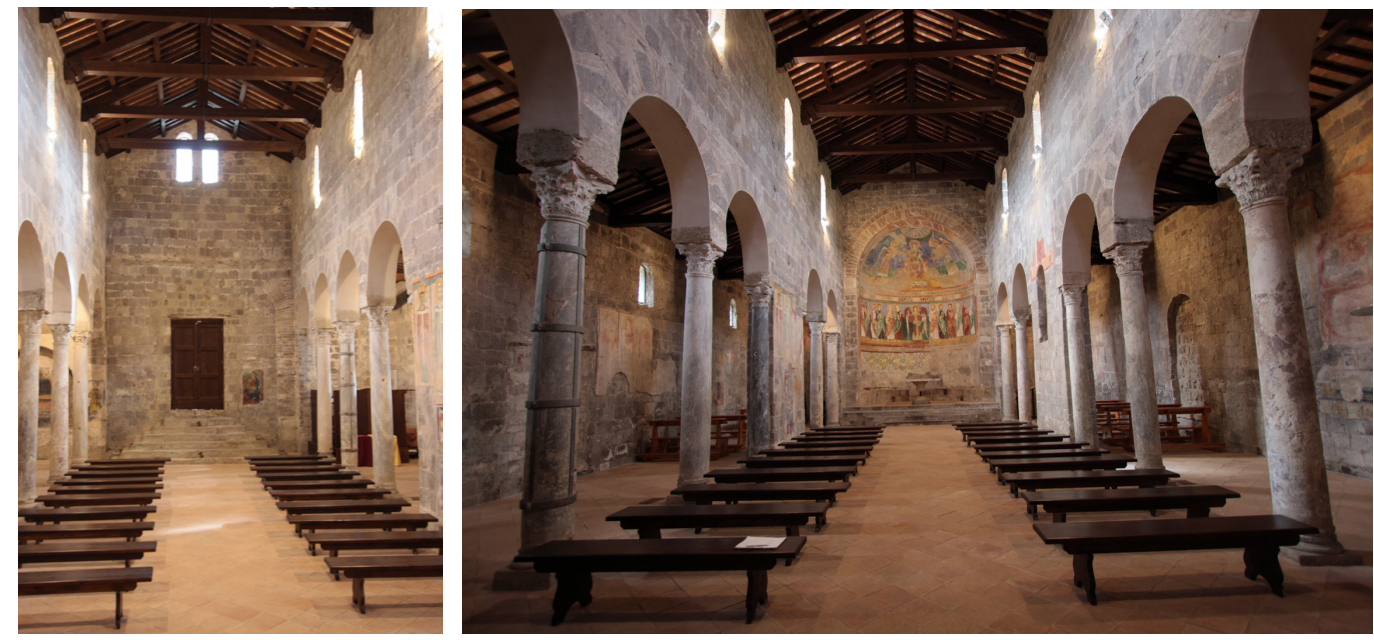

\section{Surveying and rendering}

In this specific case, the metric and photographic survey followed the phase of documentary research made at the archives of the Department of Archaeology, Fine Arts, and Landscape in the Provinces of Caserta-Benevento and Naples, the Historical Archives of the Municipality of Carinola, and the diocese of Sessa Aurunca. The latter, in particular, contained documents from the churches of Ventaroli and Carinola following the suppression of this episcopal site after an agreement between the Holy See and the Bourbons.

To reach the objectives, a surveying project was developed to understand and represent the building as a whole, along with details about the architectural, material, structural, and decorative elements. As a result, the activities were organized into different phases and levels of investigation. The surveying project integrated various methods and techniques in both the data acquisition and post-processing rendering phases to expand the operational possibilities and effectiveness of the results. Simultaneous with the first phase of effective 'contact' with the construction -made through direct surveying aimed at acquiring metric/ dimensional information, especially of the details- a 'traditional' photographic campaign was undertaken with a digital Canon EOS 40D. Once this first initial approach was complete, the activities continued with a massive instrumental survey made with the FARO Focus 3D SI20 laser scanner, in which 19 medium-resolution scans were acquired of both the interior and exterior of the building.

In the subsequent phase to process the data, interfering elements were removed. These included physical elements not related to the building, outliers deriving from scanning er- 
Fig. 6. Apse area see from outside the Basilica of Santa Maria in Foro Claudio.

Fig. 7. Detailed partial view of the presbytery. The series of painting in the larger apse can seen in the background. rors due to highly reflective surfaces, humidity and/or dust, and also 'noise' caused by mixed pixels, for example.

The data acquisition phase served to identify and note appropriate eidotypes, a series of very visible and recognizable points both inside and outside the building. These targets, once aligned from different stations with the Leica TCR 703 total station, were used in the process to combine the different point clouds, thereby enabling a common system of reference to be structured. With regard to data processing (union of clouds, development of plans, profiles, and ortho-images), JRC Reconstructor software by Gexcel was used. The processed data were then exported and treated using CAD software for the more traditional definition of the architecture, while operations relating to post-processing (editing, texturing, and meshing) were performed using two open-source programs -CloudCompare and MeshLab- used in accordance with the goals of the representation (fig. 8).
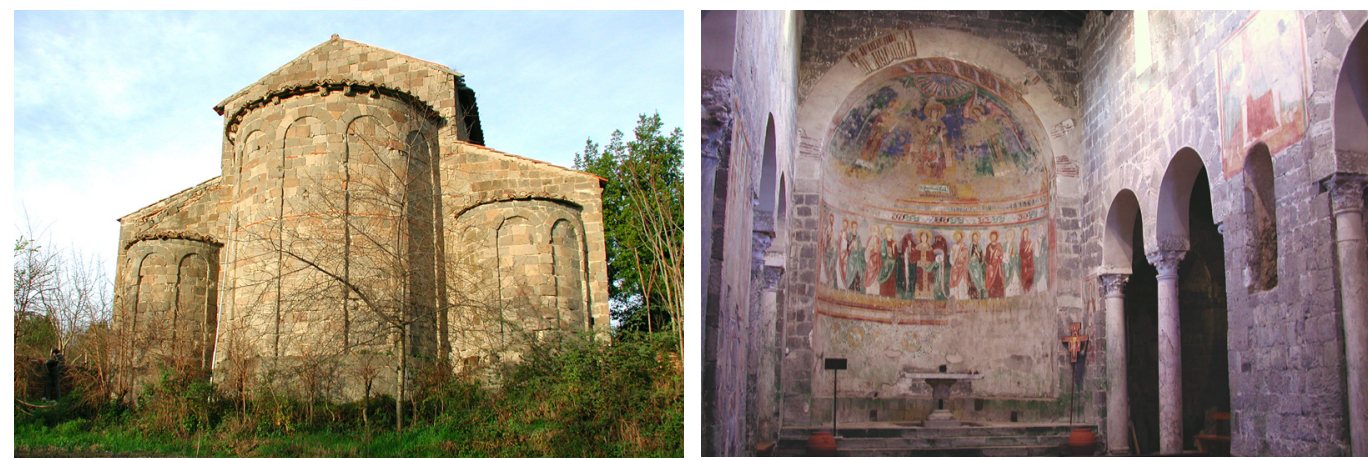

\section{Graphical/metric analysis}

Based on the metric-scale reconstructions made in the CAD environment by processing the data deriving from the acquisitions, the study focused on identifying a system of measurement that could have plausibly been adopted to build the structure, also considering the absence of metric studies dedicated to this building. In relation to particular aspects of the geographic area and period when the building was constructed, it is necessary to preface this by saying that the canons of measurement used in various buildings destined for worship are characterized by substantial openness and variability depending on a wide range of factors, including theoretical/mystagogical factors for example, among many others. Nevertheless, the Basilica of Santa Maria in Foro Claudio can be included in the series of buildings designed according to the compositional scheme of the 'Desiderian Renaissance', the eleventh-century cultural thread whose first and most illustrious supporter was the abbot Desiderio di Montecassino. As suggested by Giovanni Carbonara, the model of church wished for by Desiderio was 'ancient and modern at the same time' [Carbonara 20 14, p. 27]. Nevertheless, momentarily overlooking possible considerations about geometric/proportional characteristics, it emerges in metric terms that the cubit was the unit of measurement used by Leone Marsicano in I 159 to describe the dimensions of the environments in the Abbey of Montecassino, which was consecrated in 1071 [Aceto, Lucherini 2001, pp. 47-49]. More contemporaneously, the use of the Roman foot and Italian cubit can be observed for the Benedictine Church of Sant'Angelo in Formis, with the prevalence of the former [Carbonara 2014, p. 174]. To continue our discourse, it is practical to consider various aspects that may be useful for reasonably determining which effective measuring canon may have been used to realize the building. 


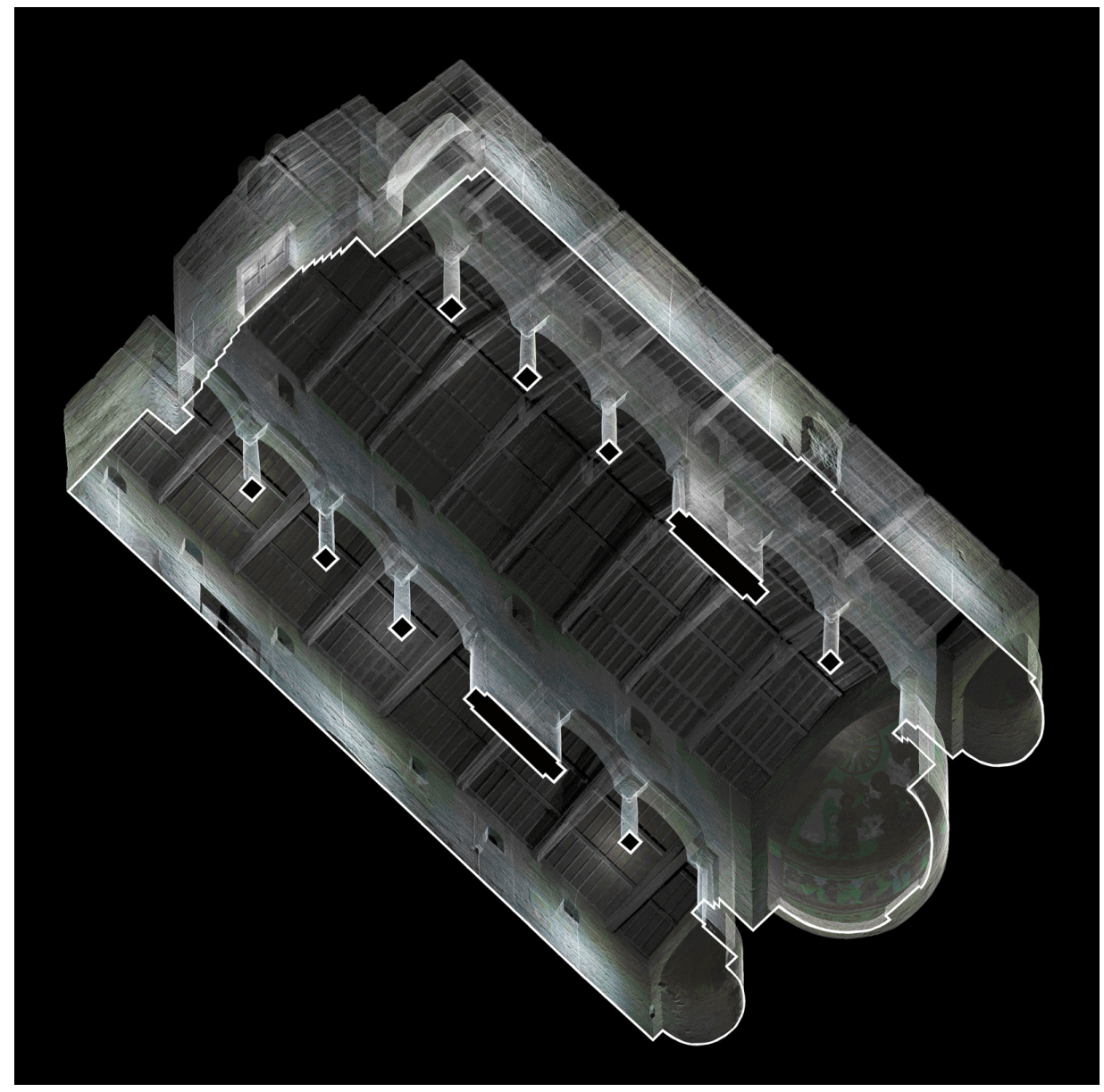

\section{The cubit}

With regard to metrology, in addition to the royal cubit and the short cubit, its submultiple, the Italian cubit and Roman foot were also used, which, while with limited differences in length on the order of millimetres, represents the reference, i.e. the originating module, for all 'variations' of the cubit.

In effect, 7 Roman feet correspond to 4 royal cubits, each $525 \mathrm{~mm}$ in length, while 3 Roman feet correspond to two submultiples of the royal cubit, that is, the short (natural) cubit. Ultimately, 'One can distinguish a natural cubit and a royal cubit modular to the former in terms of palms, 7:6, i. e. a palm more, but more useful for measuring the system of works compared to the former, the natural cubit, which is more practical for local measurement of the architectural details' [Aiello 20 8, p. 5 I].

The Italian cubit, also composed of 6 palms, instead has a unit length of $444 \mathrm{~mm}$ [Segrè 1927, pp. I 40, I4 I], corresponding to $74 \mathrm{~mm}$ per palm. This module then has a ratio of 6:9 with the Roman foot, in this case measuring 296 mm (fig. 9).

With this information, the plan of the basilica sectioned at a height of $20 \mathrm{~cm}$ above the interior floor [2] was compared in the CAD environment with two different metric devices, one composed of modules corresponding to royal cubits and the related short cubits, the other composed of Italian cubits. In both cases, the corresponding measurements in Roman feet were reported.

A comparison of the plan of the building excluding the apse profiles -represented with a rectangle as consistent as possible with the non-regular profile of the layout [3]- and the prepared measurement devices highlighted [4] the full dimensional correspondence with the royal cubit. 
Fig. 9. Dimensional relationships between Roman feet, royal cubits, and Italian cubits.
In addition, but no less important, are the results from the correspondence between the dimensional value expressed in cubit and related submultiples with respect to Roman feet. Given the dimensional values of length and width of the building, equal to 39 royal cubits and 3 palms by 26 royal cubits and 2 palms, respectively, this corresponds to a pair of whole values, that is, 69 by 46 Roman feet (fig. I0). In light of this, it is probable that the building was designed and built with the combined use of Roman feet and cubits, with the possible prevalence of the former, as also observed in the Benedictine Church of Sant'Angelo in Formis.

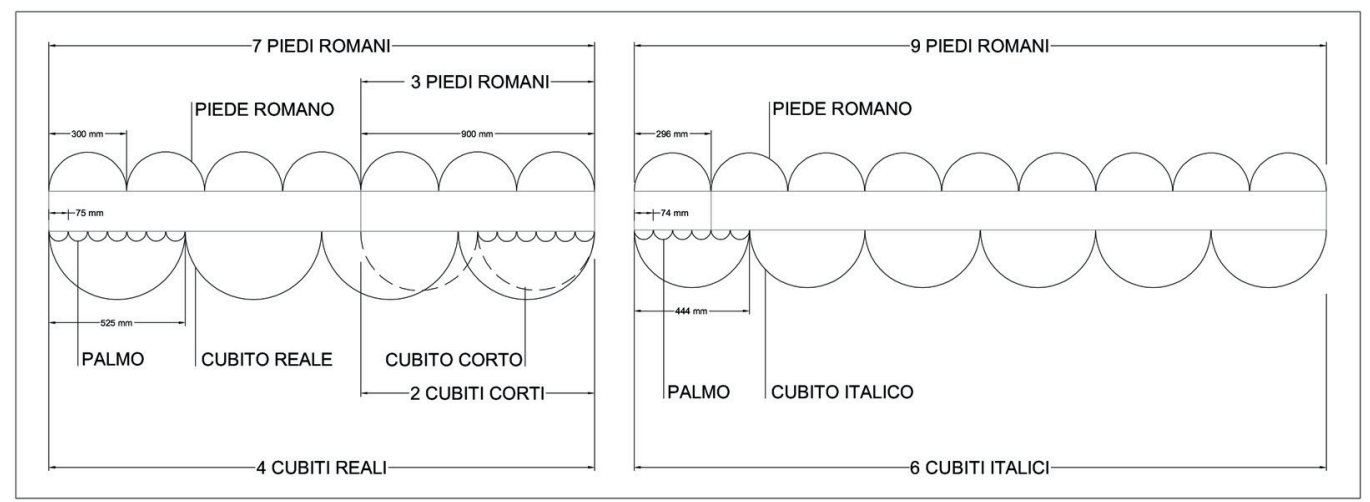

\section{The proportions}

Once the relationship between length and width of the building was identified, it was necessary to consider related proportional data. In particular, the dimensional relationship between the two sides, [a] for the width and [b] for the length, define a harmonic rectangle, particularly the one corresponding to the harmonic fifth, which has a ratio $[\mathrm{a} / \mathrm{b}]=0.6666 \ldots$ $[\mathrm{b} / \mathrm{a}]=1.5$, and therefore a ratio of 2:3 [5] (fig. I I). With regard to the study of interior proportions, the relationship between the inner diameter of the larger apse and the length of the church was identified. In particular, 4 times the diameter equals the interior length of the building measured at the exterior line of the threshold. As is known, in the Middle Ages, a module equal to the apse diameter was used as a recurring system to proportion worship halls, regulating the length and also sometimes the width [6].

With regard to metrological data, it can be seen that the diameter, I I natural cubits, agrees with the unit of measurement primarily used for local and detailed measurements. This consideration is also confirmed by the dimensional data shown in the visible transverse section in Figure 12. The interior height of the church with respect to the intermediate height of the current floor -very probably not at its original height [7]- corresponds to 25 natural cubits. The impost of the apse dome is situated at 13.5 cubits, while the height of the imposts of the arches over the longitudinal diaphragms is equal to 8.5 natural cubits.

\section{Conclusions}

As explained above, the studies presented in this article fall within a broader programme aimed at understanding and documenting the entire building. This contribution, which is certainly not exhaustive, may nevertheless open the doors to a possible key to interpreting the building. Starting with measurement and passing through geometry, it leads to the horizon of mystagogy, in turn a tool of investigation but also echoing the more physical theories formulated previously. Ultimately, it serves as a trigger for a series of continual references suspended between the tangible and intangible, between evidence and latency. 
Fig. 10. Graphical/metric analysis of the plan of the walls and proportion

relationships of the
Basilica of Santa Maria in Foro Claudio.

Fig. I I. Graphical analysis of the plan of the walls and proportional relationship of the Basilica of Santa Maria in Foro Claudio.
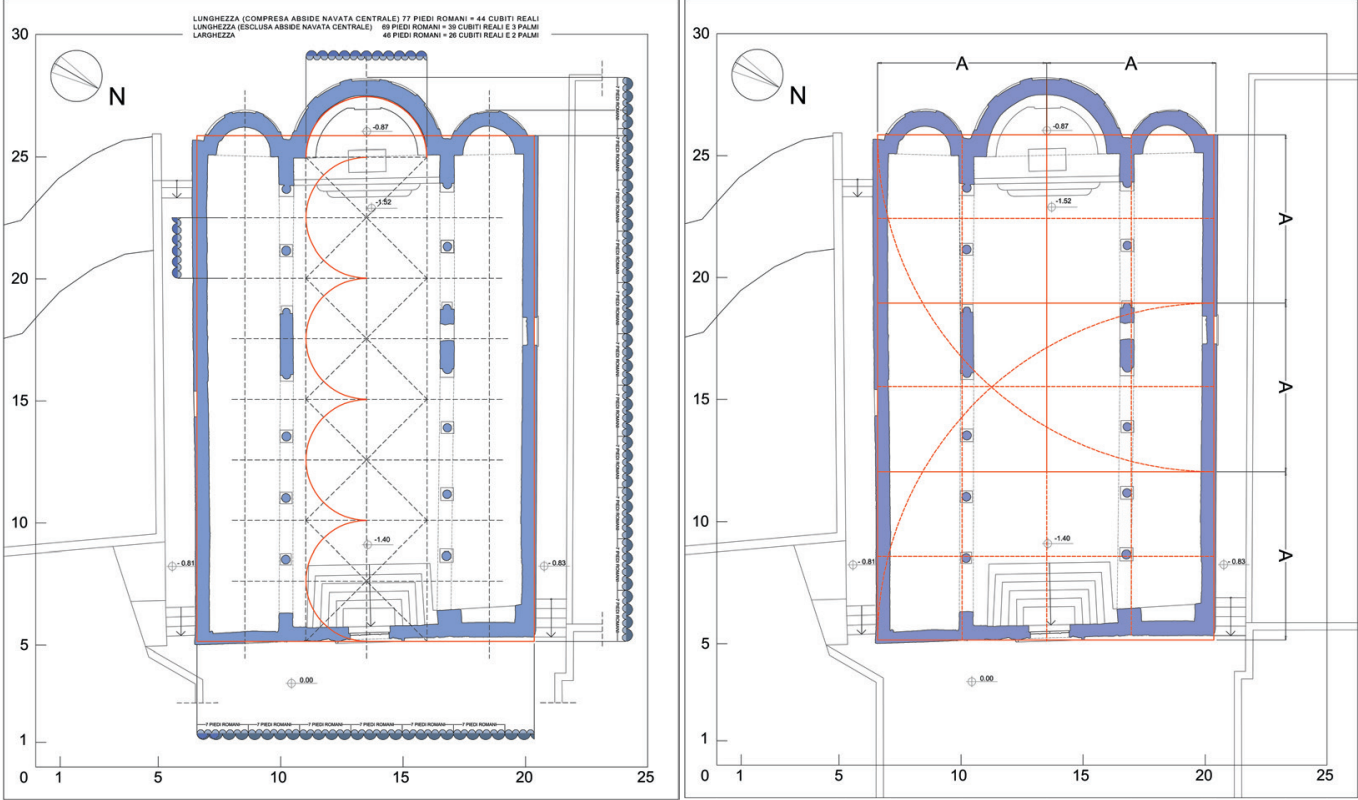

Fig. 12. Graphical/metric analysis of the transverse section of the Basilica of Santa Maria in Foro Claudio. The trace

represents the projection of the salient over the central nave. Note

how the reference of

measurement in elevation is based on natural cubits.

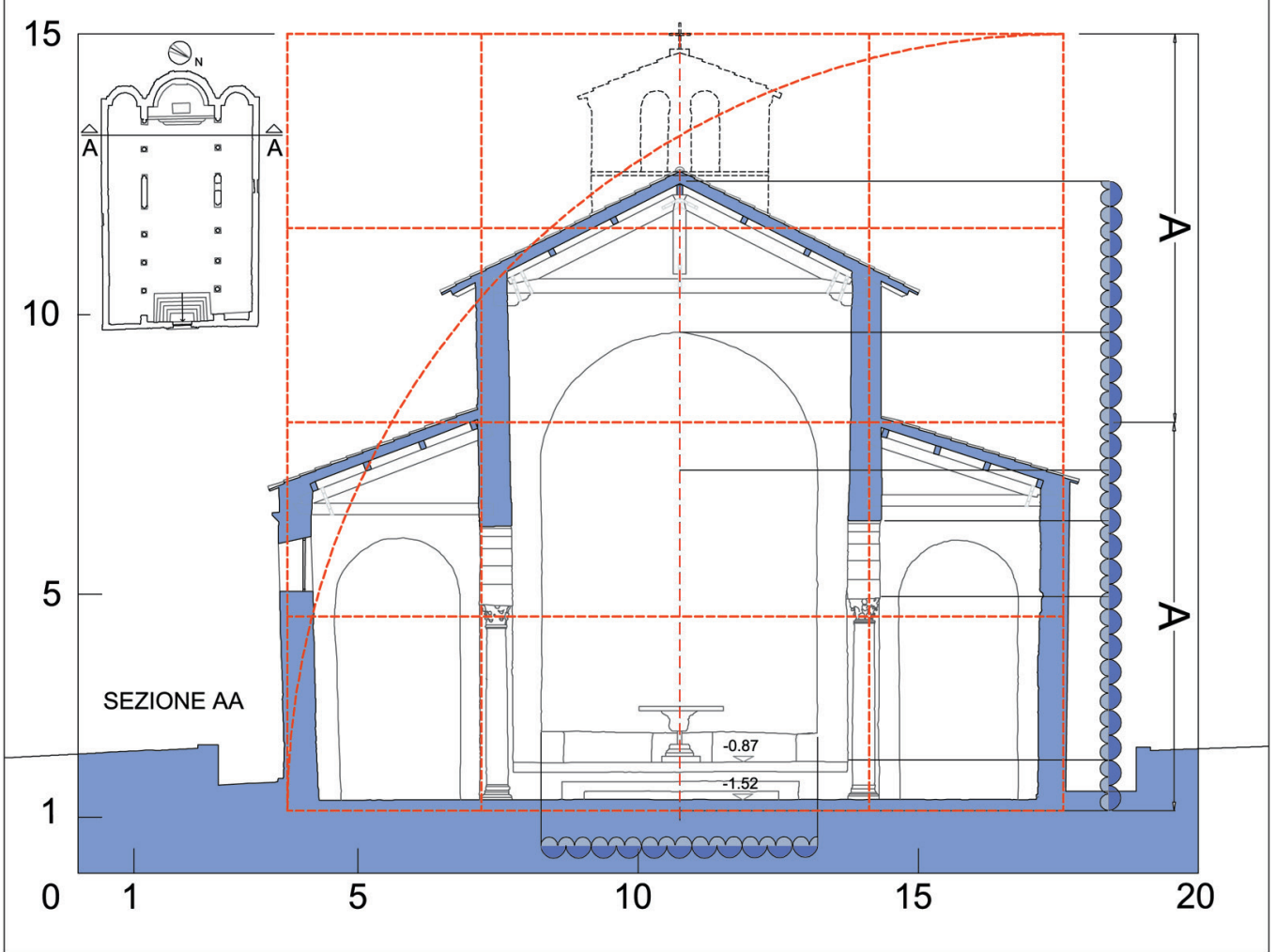




\section{Notes}

[I] For more information see, for example: Barlozzini, Carnevali, Lanfranchi 2020.

[2] A necessary choice for limiting deformations due to the progressive vertical changes in the stonework caused by ancient settling that was later reduced by consolidation work

[3] The survey map highlights the convergence of the 2 side wall sections of $10-12 \mathrm{~cm}$ towards the entrance facade as well as the $20-\mathrm{cm}$ rotation of the 2 shorter façades with respect to the axis, likely evidence of how the layout derived from other structures that would have influenced the trace of the walls and their orientation.

[4] In the objective limits of the approximation related to the uncertainty of the procedures and measurement tools used, as well as possible human error [Docci, Maestri 2009].

[5] For more information, see Dotto 2002, pp. 75-80.

[6] With regard to this type of proportioning see, for example, Acierno 2013, p. 188.

[7] Surveying graphics show that the floor, laid during the last restoration, slopes towards the presbytery by about $15 \mathrm{~cm}$ [Barlozzini, Carnevali, Lanfranchi 2020, pp. 9, 10].

\section{References}

Aceto F., Lucherini V. (a cura di). (200 I). Leone Marsicano Cronaca di Montecassino (III 26-33). Milano: Jaca Book, pp. 47-49.

Acierno M. (20 I3). Magistra Latinitas. L'architettura dell'XI secolo in Terra di Lavoro tra permanenza e innovazione. Roma: Ginevra Bentivoglio EditoriA.

Aiello L. (2018). Il cubito biblico. Misura di tutte le cose. Firenze: Didapress.

Barlozzini P., Carnevali L., Lanfranchi F. (2020). La basilica di Santa Maria in Foro Claudio a Ventaroli: analisi e rilievo di un periferico monumento medievale. In Quaderni dell'Istituto di Storia dell'Architettura, n.s. 72. Roma: L'Erma Di Bretschneider, pp. $5-18$

Carbonara G. (20|4). Iussu Desiderii, Montecassino e l'architettura campano-abruzzese nell'XI secolo. Roma: Ginevra Bentivoglio EditoriA.

Crova C. (2005). Murature medievali in opus quadratum: il Lazio meridionale e la Terra di Lavoro. Raffronti e specificità costruttive. In: D. Fiorani, D. Esposito (a cura di). Tecniche costruttive nell'edilizia storica, pp. I05-I I 8. Roma: Viella.

Docci M., Maestri D. (2009). Manuale di rilevamento architettonico e urbano. Bari: Laterza.

Dotto E. (2002). Il disegno degli ovali armonici. Catania: le Nove Muse Editrice.

Marini Ceraldi A. (1990). La basilica di S. Maria in Foro Claudio. Marina di Minturno: Armando Caramanica Editore.

Miraglia F., Valente C. (20I3). Note sulla continuità del mondo antico nell'architettura sacra e nella scultura del medioevo tra la Campania Felix ed il Latium adiectum. I casi di Carinola, Sessa Aurunca e Minturno. Marina di Minturno: Armando Caramanica Editore.

Segrè A. (1927). Metrologia e circolazione monetaria degli antichi. Bologna: Zanichelli.

Tosco C. (2016). L'architettura Medievale in Italia 600-1 200. Bologna: il Mulino.

\section{Authors}

Piero Barlozzini, Università degli Studi del Molise, piero.barlozzini@unimol.it

Laura Carnevali, Sapienza Università di Roma, laura.carnevali@uniroma l.it

Fabio Lanfranchi, Sapienza Università di Roma, fabio.lanfranchi@uniromal.it

To cite this chapter: Barlozzini Piero, Carnevali Laura, Lanfranchi Fabio (2021). Dal rilievo all'analisi grafica della basilica di Santa Maria in Foro Claudio a Ventaroli/From surveying to graphical analysis of the Basilica of Santa Maria in Foro Claudio in Ventaroli. In Arena A., Arena M., Mediat D., Raffa P. (a cura di). Connettere. Un disegno per annodare e tessere. Linguaggi Distanze Tecnologie. Atti del $42^{\circ}$ Convegno Internazionale dei Docenti delle Discipline della Rappresentazione/Connecting. Drawing for weaving relationship. Languages Distances Technologies. Proceedings of the $42^{\text {th }}$ International Conference of Representation Disciplines Teachers. Milano: FrancoAngeli, pp. 197-214. 